Prihanto, Sudiro, Martha Irene. K

Analisis Penyebab Putus Obat Pada Penderita HIV/AIDS Yang Berobat Di Klinik VCT

\title{
Analisis Penyebab Putus Obat Pada Penderita HIV/AIDS Yang Berobat Di Klinik VCT
}

\author{
Prihanto $^{1}$, Sudiro ${ }^{2}$, Martha Irene $\mathbf{K}^{3}$ \\ ${ }^{1)}$ Akademi Keperawatan Ngesti Waluyo Parakan \\ ${ }^{2,3)}$ Fakultas Kesehatan Masyarakat Universitas Diponegoro
}

Korespondensi penulis: prihantonw@yahoo.co.id

\begin{abstract}
Abstrak
Jumlah penderita HIV/AIDS di Kabupaten Temanggung sampai akhir Tahun 2014 mencapai 260 penderita dan angkanya cenderung meningkat. Dari jumlah tersebut yang masih aktif menggunakan ARV hanya 107 penderita (41\%), yang putus obat sejumlah 10 penderita (9\%).Tujuan dari penelitian ini adalah untuk menganalisa penyebab putus obat pada Penderita HIV/AIDS yang berobat di Klinik VCT Kabupaten Temanggung. Penelitian ini merupakan penelitian kualitatif, menganalisis penyebab putus obat ditinjau dari edukasi, akomodasi, modifikasi faktor lingkungan sosial, perubahan model terapi dan meningkatnya interaksi tenaga kesehatan dengan penderita. Pengambilan data dilakukan dengan melakukan wawancara mendalam terhadap informan utama yaitu 3 penderita HIV yang putus obat, 1 penderita yang masih aktif dan informan triangulasi pengelola KPA, Pengelola Klinik VCT, Kasi P2M Dinas Kesehatan dan KDS Smile Plus di Kabupaten Temanggung. Data diolah dan dianalisis berdasarkan kelima faktor tersebut dengan metode pengolahan diskripsi isi (content analysis). Hasil penelitian menunjukkan bahwa faktor penyebab putus obat adalah: 1).edukasi yang kurang berkelanjutan dan mendalam, 2). akomodasi dan fasilitas penderita yang kurang dan jarak tempuh, 3). sedangkan dari KPA adalah sarana dan prasarana yang kurang untuk memonitor penderita. Modifikasi faktor lingkungan perlu dilakukan akibat adanya stigma dari masyarakat yang dirasakan oleh penderita, dukungan dari keluarga cukup tapi tekanan dari luar lebih kuat terutama stigma yang ada, kurangnya dukungan dari tenaga kesehatan dan motivasi diri yang kurang, serta perubahan model terapi terkait dengan keluhan efek samping ARV yang dirasakan. Faktor lain adalah kebijakan dan regulasi dari pemerintah daerah terkait dengan sarana prasarana, pendanaan dan sistem koordinasi serta monitoring dalam penanganan penderita HIV/AIDS yang masih kurang memadai. Faktor pendukung pada penderita yang aktif adalah: dukungan dari tenaga kesehatan dan keluarga, serta komitmen penderita untuk terus menjalani pengobatan.
\end{abstract}

Kata Kunci: HIVIAIDS; putus obat; anti retroviral virus; klinik VCT

\section{PENDAHULUAN}

AIDS merupakan sindrom dari berbagai gejala dan tanda - tanda penyakit yang terjadi oleh karena lemahnya sistem kekebalan tubuh sebagai dari akibat dari infeksi HIV. AIDS adalah fase terakhir dari penyakit HIV dan ditandai munculnya berbagai infeksi oportunistik yang merupakan kelanjutan dari gagalnya daya tahan tubuh. Penularan HIV/AIDS terjadi tidak hanya melalui hubungan seksual tetapi juga melalui IDU (Injectable Drug Use) dan MTCT (Mother to Child Transmission) (Weinrich, 2000).

Dewasa ini HIV/AIDS menjadi penyakit endemik yang menyerang jutaan penduduk di dunia. HIV/AIDS juga merupakan masalah nasional yang harus mendapatkan perhatian dan penanganan yang serius dari semua pihak, HIV/AIDS bukan 
Prihanto, Sudiro, Martha Irene. K

Analisis Penyebab Putus Obat Pada Penderita HIV/AIDS Yang Berobat Di Klinik VCT

hanya sekedar masalah penyakit menular tetapi juga menjadi sumber masalah perkembangan yang kompleks karena menyangkut dimensi sosial, budaya, hukum, ekonomi, etika, fisik dan psikis eksistensi manusia.

Di Indonesia upaya penanggulangan HIV AIDS telah dilakukan hal ini dibuktikan dengan didirikannya Komisi Penanggulangan AIDS (KPA) sesuai dengan Peraturan Pemerintah no. 75 Tahun 2006 tentang Komisi Penanggulangan AIDS Nasional yang kemudian diikuti dengan Peraturan Menteri Dalam Negeri No. 20 Tahun 2007 tentang Pedoman Umum Pembentukan Komisi Penanggulangan AIDS Dan Pemberdayaan Masyarakat Dalam Rangka Penanggulangan HIV dan AIDS di Daerah, sedangkan penanggulangan HIV dan AIDS Propinsi Jawa Tengah diatur dalam Perda Jawa Tengah no. 6 tahun 2009, serta pembentukan KPA tingkat Kabupaten diseluruh Indonesia.

Pengobatan ARV (anti retroviral Virus) pada penderita yang positif juga merupakan salah satu bentuk penanggulangan penyakit HIV/AIDS yang bertujuan memperpanjang umur harapan hidup orang dengan HIV/AIDS (ODHA). ARV bekerja melawan infeksi dengan cara memperlambat reproduksi HIV dalam tubuh. Umumnya ARV efektif digunakan dalam bentuk kombinasi, bukan untuk menyembuhkan, tetapi untuk memperpanjang hidup ODHA, membuat mereka lebih sehat, dan lebih produktif dengan mengurangi viremia dan meningkatkan jumlah sel-sel CD4 (Yuniar, 2013).

Data di Jawa Tengah Jumlah ODHA sampai tahun 2014 menempati urutan ke 6 (enam) dari seluruh provinsi yang ada di Indonesia, yaitu sebesar 3.767 orang. ${ }^{3}$ di Jawa Tengah penderita yang masih aktif menggunakan ARV berjumlah $87 \%$, data sampai bulan september 2014 penderita yang stop obat diluar pindah dan meninggal berjumlah $1,95 \%$.

Data Statistik di Dinas Kesehatan dan KPA Kabupaten Temanggung jumlah ODHA hingga bulan September 2014 adalah HIV mencapai 149 orang, AIDS 124 orang, meninggal dunia 13 orang, jumlah keseluruhan 260 orang. Penderita yang masih menggunakan ARV tercatat sebanyak 107 orang $(41,15 \%)$, ODHA yang putus obat sebanyak 12 orang $(4,39 \%)$ sisanya tidak terdeteksi (Data Rekam medik RSUD Djojonegoro Kabupaten Temanggung, 2014). Dari Jumlah di atas faktor penyebabnya adalah Heteroseksual 170 (62,27 \%) kasus, Narkoba/ IDUs/Penasun 73 (26,73 $\%)$ kasus, Perinatal $18 \quad(6,59 \%)$ kasus, Homoseksual 12 (4,39 \%) kasus. Kabupaten Temanggung menduduki peringkat ke 18 (delapan belas) dari seluruh kota dan kabupaten yang ada di Propinsi Jawa Tengah.

Secara kuantitatif angka penderita yang putus obat memang rendah, namun secara kualitatif masih merupakan ancaman untuk terjadinya penularan, sehingga perlu mendapat perhatian yang lebih. Dampak dari ketidak patuhan berobat tersebut juga akan menimbulkan masalah baru karena pengobatan ARV pada ODHA bersifat berjenjang dan obatnya saling keterkaitan, sehingga kepatuhan berobat bagi penderita HIV/AIDS sangat disarankan. Saat ini banyak ODHA yang sudah 
Prihanto, Sudiro, Martha Irene. K

Analisis Penyebab Putus Obat Pada Penderita HIV/AIDS Yang Berobat Di Klinik VCT

menjalani terapi tetapi masih belum mengerti secara jelas mengenai semua aspek pengobatannya, termasuk dampak dari ketidakpatuhan, efek samping, kombinasi obat, serta bagaimana menjangkau obat tersebut (Niven, 2002).

Dari hasil studi pendahuluan yang dilakukan peneliti pada bulan Oktober 2014 terhadap ODHA yang berobat di Klinik VCT RSUD Djojonegoro Kabupaten Temanggung, di dapatkan data bahwa satu penderita saat menerima obat ARV langsung memindahkan obat kebotol yang sudah dipersiapkan dari rumah yang bertuliskan Multivitamin, sementara penderita yang lain terlihat ragu-ragu ketika akan memasuki klinik VCT selain itu hasil wawancara dengan salah satu Penderita HIV/ADS yang putus obat didapatkan alasan bahwa penyebab putus obat adalah karena efek obat yang malah membuat tidak sehat yaitu pusing dan mual, serta bosan kalau harus minum obat terus menerus.

Perumusan masalah dalam penelitian ini adalah data dari Dinas Kesehatan dan KPA Kabupaten Temanggung sepanjang tahun 2014 menunjukkan dari 260 penderita HIV/AIDS yang masih aktif mengambil dan menggunakan ARV di Klinik VCT tercatat hanya 107 orang $(41 \%)$ saja sedangkan jumlah Penderita yang putus obat selama tahun 2014 sebanyak 12 orang $(6,94$ $\%)$. Oleh sebab itu sangat penting untuk mengetahui apa saja yang menjadi penyebab putus obat/ketidakpatuhan penderita HIV/AIDS yang berobat di Klinik VCT RSUD Djojonegoro Kabupaten Temanggung.
Berdasarkan uraian di atas maka peneliti ingin melakukan penelitian dengan judul "Analisis Penyebab Putus Obat Pada Penderita HIV/AIDS yang Berobat di Klinik VCT RSUD Djojonegoro Kabupaten Temanggung".

\section{METODE}

Penelitian ini menggunakan rancangan kualitatif yang disajikan secara deskriptif eksploratif, melalui wawancara mendalam faktor yang menyebabkan putus obat pada penderita HIV/AIDS. Klinik VCT RSUD Djojonegoro Kab.Temanggung dan di rumah penderita HIV/AIDS yang sudah tidak pernah berobat atau putus obat di Klinik VCT RSUD Djojonegoro Kabupaten Temanggung.

Informan utama penelitian adalah Penderita positif HIV/AID sebanyak 3 orang. Informan triangulasi dalam penelitian ini adalah Petugas KPA Kabupaten Temanggung, Dokter Penanggung jawab Program, manajer kasus, (KDS) Petugas Klinik VCT RSUD Djojonegoro Kabupaten Temanggung, dan Kasubsi P2M Dinas Kesehatan Kabupaten Temanggung.

Data yang diambil dalam penelitian ini adalah data primer melalui wawancara mendalam dan observasi sedangkan data sekunder diambil melalui telaah dokumen. Setelah pengumpulan data selesai dilaksanakan maka data dianalisis menggunakan metode analisis isi (content analysis), yaitu pengumpulan data, reduksi data, dan penyajian data dan menarik kesimpulan. 
Prihanto, Sudiro, Martha Irene. $\mathrm{K}$

Analisis Penyebab Putus Obat Pada Penderita HIV/AIDS Yang Berobat Di Klinik VCT

HASIL

1. Edukasi

Semua penderita HIV AIDS sudah menerima pendidikan dan informasi terkait dengan HIV/AIDS sebelum mereka memulai program pengobatan ARV, setelah dinyatakan HIV positif dilanjutkan dengan konseling oleh petugas, dengan materi tentang penyakit HIV/AIDS dan bagaimana menejemen pengobatanya, perawatan, pola hidup dan cara penularanya dengan harapan penderita paham betul bagaimana menjalani hidup supaya aman dan tidak menularkan ke orang lain.

"Saya tahu sedikit, karena sudah pernah dijelaskan oleh petugas dari klinik VCT sebelum memulai pengobatan " (IU.1)

“ Karena sudah pernah di jelaskan saya jadi tahu sedikit-sedikit, dan di ulang saat ambil obat " (IU.2)

" Tahu sedikit pak, sudah pernah diberitahu, tapi sudah lama waktu saya mau berobat " (IU.3)

"Pernah di beritahu sebelum memulai program pengobatan, dan setiap mau mengambil obat oleh petugas” (IU.4)

Edukasi lanjutan selalu diberikan saat mereka mengambil obat ARV di Klinik VCT, maka bagi penderita yang tidak mengambil obat/putus obat maka kehilangan informasi/edukasi lanjutan dan support dari petugas, hal tersebut dapat mempengaruhi putus obat. Alasan putus obat lainnya adalah karena efek samping obat yang dapat mengganggu

\section{Akomodasi}

Akomodasi yang berhubungan dengan sarana pasarana yang di miliki penderita, sarana transportasi, dan jarak tempuh lebih dari $30 \mathrm{Km}$ menjadi masalah dalam kepatuhan berobat. Transportasi dan faktor ekonomi menjadi hambatan dalam aktifitas dan pekerjaan serta kejenuhan dalam mengkosnumsi ARV. Penyebab kurang pengetahuan yang putus obat adalah karena kurangnya informasi dari tenaga kesehatan yang kontinyu sementara penderita yang tidak putus obat menyampaikan paham betul karena setiap kali mengambil obat dijelaskan ulang.

mengakses ARV, biarpun ARV diberikan Gratis. Sarana dan prasarana dari penyedia layanan tidak mengalami hambatan semua berjalan dengan baik karena disediakan oleh pemerintah daerah dan pusat, belum pernah mengalami kekurangan stok obat ARV.

“ Ya..itu pak tadi sudah saya sampaikan untuk ke Rumah sakit harus naik angkudes dan bus, karena tidak punya kendaraan sendiri, kalau pas sehat si..tidak masalah, tapi kalau lagi masuk angin jan..membuat aras arasen untuk ambil obat disamping itu kan saya harus bekerja' (IU.1)

"Saya biasa pakai motor pak, kan dekat". (IU.2)

“Biasanya yang mengambilkan Istri saya dengan naik Ungkudes, saya kan bekerja pak, kalau saya yang mengambil saya jadi tidak bekerja, wong antrianya berjam jam”.'( IU.3 )

“Saya ke Rumah sakit biasanya diantar suami, atau saya naik bus pak”. (IU.4)

3. Modifikasi Faktor Lingkungan Sosial Terkait stigma yang beredar di masyarakat semua informan menyatakan bahwa belum berani untuk membuka diri bahwa dirinya adalah seorang yang menderita HIV/AIDS positif. Stigma di masyarakat masih sangat kental terkait 
Prihanto, Sudiro, Martha Irene. $K$

Analisis Penyebab Putus Obat Pada Penderita HIV/AIDS Yang Berobat Di Klinik VCT

dengan penyakit HIV dan perlu sosialisasi lebih dalam lagi supaya tidak terjadi diskriminasi, disisi lain informan yang sudah membuka diri pada keluarga mendapat dukungan penuh dalam upaya patuh mengkonsumsi ARV. Ketakutan membuka diri bahwa dirinya menderita HIV/AIDS positif pada masyarakat bukan tanpa alasan hampir
$90 \%$ penderita yang berada di Temanggung belum berani membuka diri pada masyarakat karena stigma dan pengetahuan masyarakat yang sangat kurang terkait dengan penyakit HIV, bahkan pejabat pemerintah dan tokoh masyarakat yang yang HIV nya positif pun mereka belum berani membuka diri karena takut dikucilkan oleh masyarakat.

\footnotetext{
“Temen-temen dari ..temanggung waktu saya masih berobat, tapi sekarang tidak ada lagi yang mendukung, dengan keluarga pun saya belum berani terus terang, takut diusir (IU.1)

"Yang tahu kan hanya Istri dan mbakyu saya yang jadi kader kesehatan, ya mereka yang mendukung saya. Bahkan Istri saya juga HIV nya positip, hari rabu baru dia mulai minum obat”. ( IU.2)

"Ya Cuma keluarga istri dan mbok saya, saudara yang lain juga belum tahu, saya takut. Dan biasnya saya sms Bu......”. (IU.3)

" Hanya suami pak, tidak ada yang lain karena saya masih takut”. (IU.4)
}

\section{Perubahan Model Terapi}

Perubahan model terapi dengan menggunakan alat bantu sebagai pengingat seharusnya meningkatkan kepatuhan penderita HIV/AIDS, tetapi tidak selamanya demikian. Perlu persiapan khusus sebelum memulai pengobatan, karena motivasi dari dalam diri penderita sendirilah yang akan mempengaruhi kepatuhan meminum obat.

“..Kalau menurut saya ada atau tidak ada pengingat kalau itu dirasa menjadi kebutuhan ya pasti akan berusaha untuk patuh dalam meminumnya, karena kalau minum obat teratur bisa dikira-kira habisnya kapan, kalau kurang 2 hari saya sudah berobat lagi ke Rumah sakit, intinya adalah kesadaran dirilah yang paling penting “..(IU.4)

5. Meningkatnya Interaksi Tenaga Kesehatan dengan ODHA

Hubungan atau interaksi antara tenaga kesehatan dengan penderita secara umum baik, terutama saat menanggapi keluhan-keluhan dari penderita dan terbuka, sehingga penderita tidak segan untuk berhubungan atau berkomunikasi dengan petugas. Pengalaman penderita HIV/AIDS yang putus obat, saat berkomunikasi dengan petugas VCT dan petugas yang lain, mereka rata-rata menyampaikan sangat nyaman bahkan sangat akrab dan saling berbagi pengalaman khususnya adalah terkait dengan masalah program pengobatan.

\footnotetext{
"Sangat-sangat nyaman, Bu......orangnya baik dan sabar, kita sering guyonan saat ambil obat, bila perlu jangan sampai ganti petugas” (IU.1)

"Nyaman sekali pak, malah semakin akrab". (IU.2)

" Nyaman-nyaman saja si pak Bu.....orangnya baik sekali.kalau istri saya yg mengambil dia selalu titip pesan agar jangan sampai lupa minum obat”. (IU.3)

penyebab putus obat pada penderita memberikan umpan balık dan interaksı dalam penelitian ini. Hal ini dibuktikan bersifat formal dan non formal, sehinga dengan interaksi antara penderita hal ini menimbulkan rasa percaya yang
} 
Prihanto, Sudiro, Martha Irene. $K$

Analisis Penyebab Putus Obat Pada Penderita HIV/AIDS Yang Berobat Di Klinik VCT

kuat pada penderita terhadap petugas yang melayani.

\section{PEMBAHASAN}

$\begin{array}{ccr}\text { Evaluasi } & \text { setelah dilakukan } \\ \text { edukasi hampir semua informan }\end{array}$ menjawab paham sedikit, dalam hal ini bisa disimpulkan bahwa semua informan utama sudah menerima edukasi dari petugas secara kuantitatif baik, namun secara kualitatif masih kurang maksimal. Untuk menilai sejauh mana penderita memahami terkait dengan pengobatanya belum ada perangkat ataun tools sebagai indikator evaluasi formatif hasil edukasi tersebut, hal tersebut sebetulnya dalam proses edukasi sangat dibutuhkan, karena sebagai tolok ukur keberhasilan dari proses edukasi tersebut.

Tanggapan informan terkait efek ARV dan alasan putus obat sangat bervariasi. Secara konsep menghentikan pengobatan sementara maka akan menimbulkan banyak masalah, seperti resistensi, penggantian obat dengan dosis dan biyaya yang lebih mahal lagi (Spiritia, 2014). Oleh karena itu tenaga kesehatan harus melibatkan keluarga dan orang terdekat untuk selalu memantau efek samping pengobatan. Pendidikan pasien dapat meningkatkan kepatuhan sepanjang pendidikan tersebut merupakan pendidikan yang aktif, seperti penggunaan buku dan media yang menarik dengan bahasa yang disederhanakan sesuai dengan tingkat kemapuan penderita, tapi yang lebih baik lagi adalah melalui pengalaman (Niven, 2002).

Sarana dan prasarana dari penyedia layanan tidak mengalami hambatan semua berjalan dengan baik karena disediakan oleh pemerintah daerah dan pusat, belum pernah mengalami kekurangan stok obat ARV. Sistem kebijakan dalam mengakses
ARV mengikuti alur kebijakan pada pasien umum BPJS yaitu menggunakan sistem antrian Kualitas pemberi layanan sudah memenuhi syarat sebagai konselor, dan secara rutin mengikuti pelatihan-pelatihn yang bersifat daerah maupun nasional, dengan demikian maka dari sisi SDM cukup baik.

Regulasi penanganan penderita HIV/AIDS dan sistem koordinasi antara KPA, Dinas Kesehatan dan klinik VCT masih perlu ditingkatkan. Job description dan program masing masing sudah ada namun belum terintegrasi dengan baik, koordinasi hanya bersifat insidentil, regulasi tentang penanggulangan penderita yang putus obat sudah dilakukan oleh pengelola klinik VCT dengan SMS, dan di serahkan ke KPA untuk menindak lanjuti, namun belum tergambar dalam jalur koordinasi dan belum ada standar prosedur oprasional (SPO).

Berdasarkan

konsep

membangun dukungan sosial dari keluarga dan teman-teman sangat penting dan kelompok pendukung dapat dibentuk untuk membantu memahami kepatuhan terhadap program pengobatan. Disisi lain terkait dengan dukungan dari keluarga, orang terdekat dan stigma dari masyarakat juga berpengaruh terhadap tingkat kepatuhan bagi penderita HIV/AIDS. Dukungan dari keluarga dan lingkungan masyarakat terlebih adalah tokoh agama adalah sangat penting, karena mereka manjadi support system yang efektif. Tetapi kenyataanya di kabupaten Temanggung tidak demikian, tokoh masyarakat yang menderita HIV/AIDS positif pun tidak ada keberanian diri untuk membuka diri, padahal mereka sebetulnya bisa dijadikan panutan atau menjadi role model bagi penderita lainya. 
Prihanto, Sudiro, Martha Irene. $\mathrm{K}$

Analisis Penyebab Putus Obat Pada Penderita HIV/AIDS Yang Berobat Di Klinik VCT

Faktor modifikasi lingkungan sangat mempengruhi angka kepatuhan penderita HIV/AIDS, karena lingkungan yang kondusif akan membuat penderita merasa nyaman dan tidak ada rasa was-was sehingga mereka akan lebih tenang dalam menjalani kehidupanya. Demikian pula faktor pendukung dari keluarga sangat berpengaruh, karena dapat memberikan dukungan sepenuhnya, peran masyarakat juga dapat mendukung pengobatan penderita HIV/AIDS. Semua elemen harus bersatu padu untuk mengatasi HIV/AIDS sesuai dengan amanah undang-undang penanggulangan HIV/AIDS, stigma di masyarakat juga merupakan sesuatu yang mendesak untuk dibenahi dengan edukasi dan sosialisasi yang terus menerus pada masyrakat.

Perubahan model terapi seharusnya bukan merupakan masalah penderita HIV/AIDS untuk putus obat, karena semua sudah di antisipasi baik dari dokter pemberi layanan maupun petugas pengelola klinik VCT. Namun demikian masih menjadi alasan oleh penderita yang putus obat, kalau dianalisa mendalam sebetulnya pokok permasalahanya yaitu motivasi diri agar tetap sehat dan demi keluarga. Meningkatkan interaksi profesional kesehatan dengan pasien adalah sesuatu yang sangat penting tujuanya adalah untuk memberikan umpan balik pada pasien, dengan demikian akan mempererat hubungan dan komunikasi sehingga akan memberikan suport dalam pengobatan.

Kualitas interkasi antara petugas kesehatan dan pasien merupakan bagian yang penting dalam menentukan derajat kepatuhan. Ada beberapa keluhan, antara lain kurangnya minat yang diperlihatkan oleh dokter, penggunaan istilah medis secara berlebihan, kurangnya empati, tidak memperolah kejelasan mengenai penyakitnya. Pentingnya ketrampilan dalam komunikasi dan interaksi dari tenaga kesehatan akan memacu kepatuhan terhadap pengobatan penderita HIV/AIDS (Niven, 2002).

\section{KESIMPULAN}

Penyebab putus obat penderita HIV/AIDS yang berobat di Klinik VCT RSUD Kabupaten Temanggung adalah faktor : edukasi dari petugas kurang mendalam dan berkelanjutan, stigma atau pandangan negatif di masyarakat terhadap Penderita HIV/AIDS, fasilitas transportasi penderita yang kurang untuk mengakses $\mathrm{ARV}$,terutama yang jarak rumah dengan Klinik VCT lebih dari 30 Kilometer, fasilitas KPA kurang memadai, dukungan tenaga kesehatan masih lemah, motivasi diri penderita masih lemah dan efek samping obat yang dirasakan penderita. Faktor lain adalah kebijakan dan regulasi dari Pemerintah Daerah terkait dengan sarana prasarana, pendanaan dan sistem koordinasi dalam penanganan penderita HIV/AIDS yang masih lemah. 
Prihanto, Sudiro, Martha Irene. $K$

Analisis Penyebab Putus Obat Pada Penderita HIV/AIDS Yang Berobat Di Klinik VCT

\section{DAFTAR PUSTAKA}

Niven, Neil. (2002). Psikologi Kesehatan Untuk Perawat dan Profesional Kesehatan Lain. Jakarta: EGC.

Spiritia. Statistik Kasus HIV/AIDS di Indonesia. Diakses melalui http://spiritia.or.id/Stats/StatCurr.pdf// pada 26 Mei 2014.

Weinrich, Sonja. (2000). AIDS Sebuah Penyakit Mengubah Dunia. Germany: Diafaem.

Yuniar, Y., Handayani, R. S., Aryastami N., K. (2013). Faktor-Faktor Pendukung Kepatuhan Orang Dengan HIV AIDS (ODHA) Dalam Minum Obat Antiretroviral di Kota Bandung dan Cimahi. Buletin Penelitian Kesehatan. 